\title{
DETERMINATION OF QUALITY PARAMETERS AND TEST ANTIOXIDANT ACTIVITIES OF 70\% ETHANOL EXTRACT OF SEROJA LEAVES (NELUMBO NUCIFERA GAERTN.)
}

\section{RATNA DJAMIL ${ }^{1 *}$, DIAH KARTIKA PRATAMI' ${ }^{1}$,FEBI AYU PUTRI ${ }^{2}$, THALIA BREBA OCTAVIA ${ }^{2}$}

${ }^{1}$ Laboratory of Phytochemistry, Faculty of Pharmacy, Pancasila University, Jakarta, 12640, Indonesia, ${ }^{2}$ Faculty of Pharmacy, Pancasila University, Jakarta, 12640, Indonesia

*Email: ratnadjamilffup@gmail.com

Received: 01 Sep 2020, Revised and Accepted: 09 Oct 2020

\section{ABSTRACT}

Objective: The purpose of this study was to evaluated the quality parameters and analyzed the antioxidant activity of seroja leaves Nelumbo nucifera Gaertn.

Methods: The quantification of the chemical compound was determined by its total phenol and flavonoid levels. The evaluate the antioxidant activity was determined by the comparability of the four common radical scavenging assays using 2,2 -azino-bis-3-ethylbenzthiazoline-6-sulphonic acid (ABTS); 1, 1-diphenyl-2-picrylhydrazyl (DPPH) radical; cupric ion reducing antioxidant capacity (CUPRAC); ferric reducing antioxidant power (FRAP); and 2-thiobarbituric acid (TBA) methods.

Results: The results of phytochemical screening for simplicia powder and 70\% ethanol extract of seroja leaves contain secondary metabolites of alkaloids, flavonoids, saponins, tannins, coumarin, quinones, and triterpenoid steroids. The results of the determination of the quality parameters meet the requirements of quality and safety standard of the medicinal herb. The result of the determination of total phenol content from $70 \%$ ethanol extract of Seroja leaves was $181.62 \pm 0.82 \mathrm{mg} \mathrm{GAE} / \mathrm{g}$ extract. The results of the determination of total flavonoid levels from $70 \%$ ethanol extract of seroja leaves amounted to $289.83 \pm 1.04 \mathrm{mg} \mathrm{QE} / \mathrm{g}$ extract. The results of antioxidant activity tests using the ABTS, DPPH, and TBA methods showed $\mathrm{IC}_{50}$ respectively $287.7 \mathrm{mg} / \mathrm{l}, 22.3 \mathrm{mg} / \mathrm{l}$, and $352.6 \mathrm{mg} / \mathrm{l}$ and CUPRAC and FRAP methods had an antioxidant capacity of $160.76 \pm 0.35$ and $253.36 \pm 0.48 \mathrm{mg} \mathrm{AAE} / \mathrm{g}$ extract.

Conclusion: Seroja leaves (Nelumbo nucifera Gaertn.) have the potential to be used as an antioxidant medicinal herb and its extract meet the standard of quality control and safety.

Keywords: Seroja (Nelumbo nucifera Gaertn.), Antioxidants, ABTS, CUPRAC, DPPH, FRAP, TBA

(C) 2021 The Authors. Published by Innovare Academic Sciences Pvt Ltd. This is an open access article under the CC BY license (http://creativecommons.org/licenses/by/4.0/) DOI: http://dx.doi.org/10.22159/ijap.2021.v13s2.06 Journal homepage: https://innovareacademics.in/journals/index.php/ijap

\section{INTRODUCTION}

Currently, the use of antioxidants from natural ingredients to ward off free radicals is becoming a popular research material in the world of health. Free radicals are molecular atoms that have unpaired electrons in their outer orbitals so their reactivity is very high. An increase in the amount of free radicals in the body can cause oxidative stress, which according to some studies if it occurs continuously, can cause degenerative diseases. Antioxidants are compounds that can inhibit the oxidation process of free radicals by the mechanism of action, namely donating one of the hydrogen atoms $(\mathrm{H})$ or protons to free radical compounds so that free radical compounds can be more stable. According to several studies that have been done, the use of synthetic antioxidants in the long term can potentially cause carcinogenic [1]. The use of natural ingredients for treatment tends to increase with the people's thinking back to nature and the belief that the use of natural materials has minimum side effects. Lotus plants (Nelumbo nucifera Gaertn.) better known as swamp plants which are found in Indonesia have many benefits, one of which is as an antioxidant $[2,3]$.

\section{MATERIALS AND METHODS}

\section{Plant material}

The material used for the study was the leaves of the lotus (Nelumbo nucifera Gaertn.) obtained from the Bogor Institute of Spice and Medicinal Research (BALITR0), Bogor, West Java, Indonesia. The plant determination of the leaves of Seroja (Nelumbo nucifera Gaertn.) is carried out with the aim of macroscopically identifying the truth of the plant to be used. Determination was carried out at the Botanical Gardens Conservation Center, Bogor, West Java, Indonesia (No: B-542/IPH.3/KS/III/2019).

\section{Chemical and reagent}

neocuproin (2,9-dimethyl-1,10-phenanthroline), Copper(II) chloride dihydrate $\left(\mathrm{CuCl}_{2}\right)$, ammonium acetate, DPPH (1,1-diphenyl-2- picrylhydrazyl), TPTZ (2,4,6-tris(2-pyridyl)-s-triazine), sodium acetate trihydrate, $\mathrm{Fe}$ (III) chlorida hexahydrate $\left(\mathrm{FeCl}_{3}\right)$, gallic acid, sodium carbonate $\left(\mathrm{Na}_{2} \mathrm{CO}_{3}\right)$, Folin-Ciocalteu, methanol pro analysis, ethanol pro analysis, ascorbic acid, ammonium hydroxide 30\%, chloroform, $\mathrm{HCl}$, amyl alcohol, $\mathrm{H}_{2} \mathrm{SO}_{4}, \mathrm{CH}_{3} \mathrm{COOH}$ anhydrate, petroleum eter, sodium hydroxide $1 \mathrm{~N}$, ABTS (2,2'-azino-bis(3ethylbenzthiazoline-6-sulfonic acid), quersetin, potassium asetate, potassium persulfate, Thiobarbituric acid (TBA), phosphate buffer $\mathrm{pH} 7$, linoleic acid, trichloroacetate (TCA), acetate buffer $\mathrm{pH} 3.6$ were purchased from Sigma-Aldrich (Merck KGaA, Missouri, United States). Dragendorff reagent, Mayer reagent, Libermann-Buchard reagent, magnesium, and Gelatin solution 1\% were purchased from Q-Lab laboratory (Pancasila University, Jakarta, Indonesia).

\section{The extraction of Nelumbo nucifera gaertn}

Simplicia of seroja leaf powder was extracted by kinetic maceration using $70 \%$ ethanol solvent. The filtrate is filtered with filter paper coated with cotton to separate the pulp and filtrate. Remaceration was then concentrated using a vacuum rotary evaporator to obtain $70 \%$ ethanol viscous extract $[4,5]$.

\section{Phytochemical screening}

Preliminary examinations of secondary metabolite compounds on $70 \%$ ethanol extracts of the leaves of the lotus leaf included identification of the alkaloid, flavonoid, saponin, tannin, quinone, triterpenoid steroid, coumarin, and essential oil groups [6].

\section{Determination of extract quality parameters}

Determination of the quality parameters of $70 \%$ ethanol extract of seroja leaves includes specific parameters: organoleptic test (appearance, color, smell and taste) and determination of the percentage of dissolved compounds in certain solvents. The nonspecific parameters: determination of ash content, drying losses, water content, heavy metal contamination, microbial contamination, and residual solvents [4]. 


\section{Determination of total phenol levels}

$0.4 \mathrm{ml}$ of $70 \%$ ethanol extract of Seroja leaves added $0.4 \mathrm{ml}$ of the Folin Ciocalteu reagent (allowed to stand for $3 \mathrm{~min}$ in a dark place), $4 \mathrm{ml}$ of $7.5 \% \mathrm{Na}_{2} \mathrm{CO}_{3}$, and aquadest added to $10.0 \mathrm{ml}$. The solution is allowed to stand for $70 \mathrm{~min}$ at room temperature. The absorption was measured with a UV-Vis spectrophotometer at a wavelength of $759.5 \mathrm{~nm}$. The total phenol content of the $70 \%$ ethanol extract of the seroja leaf is expressed in mg Gallic Acid Equivalent/gram extract (mg GAE/g) [7].

\section{Determination of total flavonoid levels}

$1.0 \mathrm{ml}$ of $70 \%$ ethanol extract of seroja leaves were added with $3 \mathrm{ml}$ of methanol, $200 \mu \mathrm{l}$ of potassium acetate, $200 \mu \mathrm{L}$ of $\mathrm{AlCl}_{3}$ (aluminum chloride), and aquadest was added to $10.0 \mathrm{ml}$. The solution is allowed to stand for $30 \mathrm{~min}$ at room temperature. The absorption was measured with a UV-Vis spectrophotometer at a wavelength of $371.0 \mathrm{~nm}$. The total flavonoid content of $70 \%$ ethanol extract of seroja leaves is expressed in mg Quersetin Equivalent/gram extract (mg QE/g) [7].

\section{Vitamin C standard solution}

Testing the antioxidant activity of the extract with the ABTS, DPPH, and TBA methods using vitamin $\mathrm{C}$ as a positive control. Antioxidant activity is determined from the $\mathrm{IC}_{50}$ value. Measurement of the antioxidant capacity of the extract by the CUPRAC and FRAP methods uses vitamin $\mathrm{C}$ as a standard curve whose results are expressed in $\mathrm{mg}$ Ascorbic Acid Equivalent/gram extract (mg AAE/g).

\section{Antioxidant activity test ABTS method}

The test was carried out by piping a number of $70 \%$ ethanol extract sample stock solution of $1000 \mathrm{mg} / \mathrm{l}$ lotus leaves, then adding $1.0 \mathrm{ml}$ of ABTS then $5.0 \mathrm{ml}$ of volume was sufficient with ethanol. The solution is allowed to stand for $30 \mathrm{~min}$ at room temperature. The absorption was measured with a UV-Vis spectrophotometer at a wavelength of $412.0 \mathrm{~nm}$. Antioxidant activity is determined from the IC 50 value $[3,7,8]$.

\section{Antioxidant activity test CUPRAC method}

As much as $0.5 \mathrm{ml}$ of $70 \%$ ethanol extract of seroja leaves were added $1 \mathrm{ml}$ of $\mathrm{CuCl}_{2} 2 \mathrm{H}_{2} \mathrm{O}$ solution, $1 \mathrm{ml}$ of neokuproin solution, $1 \mathrm{ml}$ of $\mathrm{NH}_{4}$ Ac buffer solution $\mathrm{pH} 7$, and $4.1 \mathrm{ml}$ volume was sufficient with aquadest. The solution is allowed to stand for $30 \mathrm{~min}$ at room temperature. The absorption was measured with a UV-Vis spectrophotometer at a wavelength of $453.5 \mathrm{~nm}$. The antioxidant capacity of $70 \%$ ethanol extract of seroja leaves is expressed in $\mathrm{mg}$ Ascorbic Acid Equivalent/gram extract (mg AAE/g) $[9,10]$.

\section{Antioxidant activity test DPPH method}

The test is carried out by piping a number of $70 \%$ ethanol extract sample stock solution of $1000 \mathrm{mg} / \mathrm{l}$ leaves, then adding $1.0 \mathrm{ml}$ DPPH $0.4 \mathrm{mmol}$ and then $5.0 \mathrm{ml}$ of methanol are sufficient. The solution is allowed to stand for $30 \mathrm{~min}$ at room temperature. The absorption was measured with a UV-Vis spectrophotometer at a wavelength of 516.5 $\mathrm{nm}$. Antioxidant activity is determined from the $\mathrm{IC}_{50}$ value $[7,9,11]$.

\section{Antioxidant activity test FRAP method}

$1.0 \mathrm{ml}$ of $70 \%$ ethanol extract of seroja leaves was added with $3.0 \mathrm{ml}$ of aquadest solution, $3.0 \mathrm{ml}$ of FRAP solution. FRAP solution was prepared by mixing $25 \mathrm{ml}$ of acetate buffer $\mathrm{pH} 3.6,2.5 \mathrm{ml}$ of TPTZ solution, and 2.5 iron (III) chloride hexahydrate solution. The solution is allowed to stand for $30 \mathrm{~min}$ at room temperature. The absorption was measured with a UV-Vis spectrophotometer at a wavelength of $595.0 \mathrm{~nm}$. The antioxidant capacity of $70 \%$ ethanol extract of seroja leaves is expressed in mg Ascorbic Acid Equivalent/gram extract (mg AAE/g) [7, 9, 12].

\section{Antioxidant activity test TBA method}

The test was carried out by piping a number of $70 \%$ ethanol extract sample stock solution of $1000 \mathrm{mg} / \mathrm{l}$ leaves, then adding $2.0 \mathrm{ml}$ of 0.1 $\mathrm{M}$ phosphate buffer $\mathrm{pH} 7$ and $2 \mathrm{ml}$ of $50 \mathrm{mmol}$ linoleic acid. The solution is allowed to stand for $30 \mathrm{~min}$ at room temperature. The absorption was measured with a UV-Vis spectrophotometer at a wavelength of $532.0 \mathrm{~nm}$. Antioxidant activity is determined from the IC 50 value $[3,8]$.

\section{RESULTS AND DISCUSSION}

\section{Phytochemical screening}

Simplisia powder and $70 \%$ ethanol extract of leaves of the seroja leaves were analyzed phytochemically to determine the content of the samples used.

Table 1: Phytochemical screening results of lotus leaves

\begin{tabular}{lll}
\hline No. & Group identification & Results \\
\hline 1. & Alkaloids & + \\
2. & Flavonoids & + \\
3. & Tannins & + \\
4. & Saponins & + \\
5. & Quinones & $+/+$ \\
6. & Steroids/triterpenoids & + \\
7. & Coumarins & - \\
8. & Essential oil & \\
\hline
\end{tabular}

$(+)$ contains secondary metabolites; (-) does not contain secondary metabolites

\section{Organoleptic determination}

Organoleptic determination aims to determine the identity of the initial introduction to the extract that can be observed visually.

\section{Determination of compounds dissolved in certain solvents}

Determination of dissolved compounds in certain solvents aims to determine the amount of secondary methanolite dissolved in water and ethanol solvents.

Table 2: The result of organoleptic extract determination

\begin{tabular}{lll}
\hline No. & Extract identity & Result \\
\hline 1. & Shape & Thick extract \\
2. & Color & Blackish green \\
3. & Smell & Odorless \\
4. & Taste & Weak \\
\hline
\end{tabular}


Table 3: The result of determining the level of dissolved compounds in certain solvents

\begin{tabular}{lll}
\hline No. & Determination & Results \\
\hline 1. & Water soluble compounds & $7.59 \%$ \\
2. & Ethanol soluble compounds & $7.85 \%$ \\
\hline
\end{tabular}

Based on the results above, there are more secondary metabolites found in ethanol solvents than those found in water solvents. This result was obtained due to the use of $70 \%$ ethanol as a solvent which is a universal solvent that can attract compounds of nonpolar, semi-polar, and polar properties.

\section{Determination of non-specific quality parameters of the extract}

Determination of non-specific quality parameters aims to determine the quality of extracts that have standards and safe limits of extracts as a safe and quality natural material product.

Table 4: The results of determining non-specific quality parameters

\begin{tabular}{ll}
\hline Parameters & Results \\
\hline Loss on drying & $4.97 \%$ \\
Water content & $5.28 \%$ \\
Total ash content & $6.32 \%$ \\
Water soluble ash content & $5.13 \%$ \\
Ash content not acid solubility & $1.17 \%$ \\
Residual solvent & $0.54 \%$ \\
Lead metal contamination & $0.3684 \mathrm{mg} / \mathrm{kg}$ \\
Cadmium metal contamination & $0.1748 \mathrm{mg} / \mathrm{kg}$ \\
Total Plate Count & Not detected \\
Yeast And Mold Plate Count & Not detected \\
\hline
\end{tabular}

Table 5: The results of the determination of total phenol and flavonoid levels

\begin{tabular}{ll}
\hline Content determination & Results \\
\hline Phenol & $181.62 \pm 0.82 \mathrm{mg} \mathrm{GAE} / \mathrm{g}$ extract \\
Flavonoid & $289.83 \pm 1.04 \mathrm{mg} \mathrm{QE} / \mathrm{g} \mathrm{extract}$ \\
\hline
\end{tabular}

The data was given in mean+SD, $n=3$

\section{Determination of total phenol and flavonoid levels}

Determination of total phenol and flavonoid levels was carried out to determine the amount of compounds contained in the extract using the colorimetric principle. Determination of total phenol and flavonoid levels in the ethanol extract of $70 \%$ of Seroja leaves by the UV-VIS spectrophotometer method [13].

\section{Antioxidant activity test}

Testing the antioxidant activity with the ABTS method based on the ability of the neutralization of the sample to the amount of free radicals in the ABTS solution, this process is characterized by the fading color of the ABTS solution from yellow to purple whose absorbance can be measured using a UV-Vis spectrophotometer $[3,7]$.

Testing of antioxidant activity by DPPH method based on the reaction of hydrogen capture by DPPH radicals from antioxidants, this process is characterized by the fading color of DPPH solution from purple to yellow whose absorbance can be measured using a UV-Vis spectrophotometer $[11,14,15]$.

Testing of antioxidant activity by the TBA method is based on the reaction that occurs between 1 MDA molecule and 2 TBA molecules to produce a pink MDA-TBA complex compound. At low $\mathrm{pH}$ and high temperatures, the malondialdehyde-TBA bond will change to red MDA-TBA, whose absorption can be measured using a UV-Vis spectrophotometer $[3,7]$.

Determination of the antioxidant activity of $70 \%$ ethanol extract of Seroja leaves by the ABTS, DPPH and TBA methods can be determined from the $\mathrm{IC}_{50}$ value, namely the concentration of antioxidants that can inhibit $50 \%$ of free radicals. $\mathrm{IC}_{50}$ values were obtained from linear regression equations by entering extract concentration data as $\mathrm{x}$ values and\% inhibition data as $\mathrm{Y}$ values [7]. The result of $\mathrm{IC}_{50}$ can be seen in fig. 1.

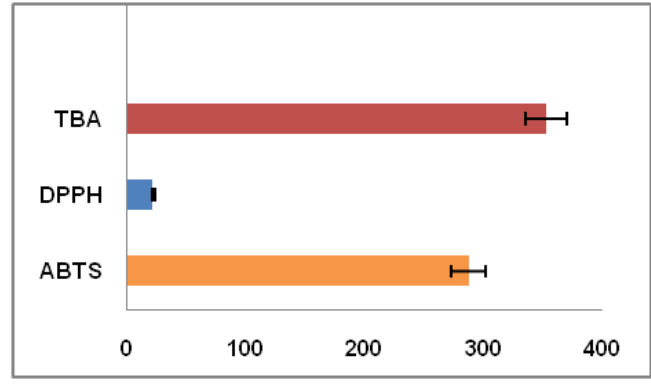

Fig. 1: Antioxidant activity test results $\left(\mathrm{IC}_{50}\right)$

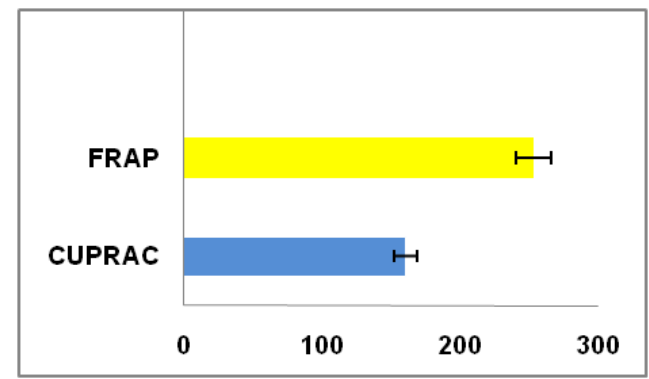

Fig. 2: Antioxidant activity test results (mg AAE/g)

Testing the antioxidant activity by the CUPRAC method based on the principle of the electron transfer mechanism by forming the bisneokuproin-copper(II) $\left(\mathrm{Cu}(\mathrm{Nc}) 2^{2+}\right)$ complex will oxidize the antioxidant compounds in plant extracts then undergo reduction to form the complex bisneokuproin-copper(I) $\left(\mathrm{Cu}(\mathrm{Nc})_{2}{ }^{+}\right)$. Blue turquoise 
$\left(\mathrm{Cu}(\mathrm{Nc})_{2} 2^{2+}\right)$ reagents will be reduced to yellow $\left(\mathrm{Cu}(\mathrm{Nc}) 2_{2}+\right)$ whose absorbance can be measured using a UV-Vis spectrophotometer $[9,10]$.

Testing of antioxidant activity by the FRAP method is based on the principle of the electron transfer mechanism by reducing the $\mathrm{Fe}^{3+}$ complex from tripiridiltriazine $\mathrm{Fe}(\mathrm{TPTZ})^{3+}$ to the $\mathrm{Fe}^{2+}$ complex. $\mathrm{Fe}(\mathrm{TPTZ})^{2+}$ will be intensely blue by antioxidants in an acidic atmosphere where absorbance can be measured using a UV-Vis spectrophotometer $[9,12]$.
Determination of the antioxidant capacity of $70 \%$ ethanol extract of Seroja leaves by the CUPRAC and FRAP methods is expressed in $\mathrm{mg}$ Ascorbic Acid Equivalent/gram extract (mg AAE/g). The antioxidant capacity of CUPRAC and FRAP methods can be seen in fig. 2.

Based on the research that has been done, the results of testing the activity and antioxidant capacity of $70 \%$ ethanol extract of Seroja leaves by the ABTS, CUPRAC, DPPH, FRAP and TBA methods can be seen in table 6 .

Table 6: Antioxidant activity test results

\begin{tabular}{lll}
\hline No. & Test & Results \\
\hline 1. & ABTS $\left(\mathrm{IC}_{50}\right)$ & $287.7 \mathrm{mg} / \mathrm{l}$ \\
2. & CUPRAC & $160.76 \pm 0.35 \mathrm{mg}$ AAE/g extract \\
3. & DPPH $\left(\mathrm{IC}_{50}\right)$ & $22.26 \mathrm{mg} / \mathrm{l}$ \\
4. & FRAP & $253.36 \pm 0.48 \mathrm{mg} \mathrm{AAE} / \mathrm{g}$ extract \\
5. & TBA $\left(\mathrm{IC}_{50}\right)$ & $352.6 \mathrm{mg} / \mathrm{l}$ \\
6. & DPPH Vitamin C $\left(\mathrm{IC}_{50}\right)$ & $3.76 \mathrm{mg} / \mathrm{l}$ \\
\hline
\end{tabular}

The data was given in mean $+\mathrm{SD}, \mathrm{n}=3$

\section{CONCLUSION}

The results of phytochemical screening for simplicia powder and $70 \%$ ethanol extract of Seroja leaves contain secondary metabolites of alkaloids, flavonoids, saponins, tannins, coumarin, quinones, and triterpenoid steroids. The results of determining the quality parameters of the extract obtained percentage of dissolved compounds in water by $7.59 \%$, dissolved compounds in ethanol $7.85 \%$, drying losses $4.97 \%$, moisture content $5.28 \%$, total ash content $6.32 \%$, content acid insoluble ash $1.17 \%$, water soluble ash content $5.13 \%$, lead metal contamination $0.3684 \mathrm{mg} / \mathrm{kg}$, cadmium metal contamination $0.1748 \mathrm{mg} / \mathrm{kg}$, residual solvent $0.54 \%$, and microbial contaminants that meet the requirements. The result of the determination of total phenol content from $70 \%$ ethanol extract of Seroja leaves was $181.62 \pm 0.82 \mathrm{mg} \mathrm{GAE} / \mathrm{g}$ extract. The results of the determination of total flavonoid levels from $70 \%$ ethanol extract of Seroja leaves amounted to $289.83 \pm 1.04 \mathrm{mg} \mathrm{QE} / \mathrm{g}$ extract. The results of antioxidant activity tests using the ABTS, DPPH, and TBA methods showed $\mathrm{IC}_{50}$ respectively $287.7 \mathrm{mg} / \mathrm{l}, 22.3 \mathrm{mg} / \mathrm{l}$, and 352.6 $\mathrm{mg} / \mathrm{l}$ and CUPRAC and FRAP methods had antioxidant capacity of $160.76 \pm 0.35$ and $253.36 \pm 0.48 \mathrm{mg} \mathrm{AAE} / \mathrm{g}$ extract. Seroja leaves (Nelumbo nucifera Gaertn.) have the potential to be used as an antioxidant medicinal herb and its extract meet the standard of quality control and safety.

\section{ACKNOWLEDGMENT}

The author gratefully acknowledged to the Q-Lab and Research Laboratory Faculty of Pharmacy University of Pancasila who have provide facilities for this research.

\section{FUNDING}

Nil

\section{AUTHORS CONTRIBUTIONS}

All the authors have contributed equally.

\section{CONFLICT OF INTERESTS}

The authors declare no conflict of interest.

\section{REFERENCES}

1. Wojcik M, Burzynska Pedziwiatr I, Wozniak LA. A review of natural and synthetic antioxidants important for health and longevity. Curr Med Chem 2010;17:3262-88.
2. Jarmkom K, Techaoei S, Wisidsri N, Khobjai W. Evaluation of acetylcholinesterase activity and cytotoxicity of different parts of Nelumbo nucifera Gaertn on human neuroblastoma cell line (SH-SY5Y). Int J Appl Pharm 2019;11:103-5.

3. Salmiyah S, Ainunnisa A, Nurmilasari N, Handayani E, Firdaus F. Identification of organic compounds from extract lotus seeds (Nelumbo nucifera). Indonesia Chim Act 2019;10:19-24.

4. Zheng LJ, Wu YB, Wu JG, Tan CJ, Yi J, Chen TQ, et al. Antioxidant activity of lotus (Nelumbo nucifera Gaertn.) receptacles of eleven cultivars grown in China. J Med Plants Res 2012;6:1902-11.

5. Djamil R, Rahmat D, Zaidan S, Latifah MN. Anticholesterol activity of okra fruit extract (Abelmoschus esculentus (L) Moench) and its nanoemulsion in vivo. Pharmacogn J 2020;12:316-20.

6. Farnsworth NR. Biological and phytochemical screening of plants. J Pharm Sci 1966;55:225-76.

7. Apak R, Gorinstein S, Böhm V, Schaich KM, Ozyurek M, Guclu K. Methods of measurement and evaluation of natural antioxidant capacity/activity (IUPAC Technical Report). Pure Appl Chem 2013;85:957-98

8. Moharram HA, MM Youssef. Methods for determining the antioxidant activity. Alex J Fd Sci Technol 2014;11:31-9.

9. Choirunnisa AR, Fidrianny I, Ruslan K. Comparison of five antioxidant assays for estimating antioxidant capacity from three Solanum sp. extracts. Asian J Pharm Clin Res 2016;9:123-8.

10. Apak R, Guclu K, Demirata B, Ozyurek M, Celik SE, Bektaşoglu $B$, et al. Comparative evaluation of various total antioxidant capacity assays applied to phenolic compounds with the CUPRAC assay. Molecules 2007;12:1496-547.

11. Molyneux P. The use of the stable free radical diphenylpicrylhydrazyl (DPPH) for estimating antioxidant activity. Songklanakarin J Sci Technol 2004;26:211-9.

12. Benzie IFF, Strain JJ. The ferric reducing ability of plasma (FRAP) as a measure of "antioxidant power": the FRAP assay. Anal Biochem 1996;239:70-6.

13. Limwachiranon J, Huang H, Shi Z, Li L, Luo Z. Lotus flavonoids and phenolic acids: health promotion and safe consumption dosages. Compr Rev Food Sci Food Saf 2018;17:458-71.

14. Djamil R, Anelia T. Penapisan fitokimia, uji BSLT, dan uji antioksidan ekstrak metanol beberapa spesies papilionaceae. J Ilmu Kefarmasian Indones 2009;7:65-71.

15. Djamil R, Wahyudi PS, Wahono S, Hanafi M. Antioxidant activity of flavonoid from Anredera cordifolia (Ten) steen is leaves. Int Res J Pharm 2012;3:241-3. 